\title{
Clinical and Non-clinical Proof of Concept Supporting the Development of RJX As an Adjunct to Standard of Care Against Severe COVID-19
}

Fatih M. Uckun ${ }^{a, b^{*}}$, Muhammad Saeed ${ }^{c}$, Mustafa Awilic, Ibrahim H. Ozercan ${ }^{d}$, Sanjive Qazi ${ }^{b}$, Cynthia Lee ${ }^{a}$, Adeel Shiblic ${ }^{c}$ Alan W. Skolnick ${ }^{e}$, Alonso Prusmack ${ }^{\dagger}$, Joseph Varon ${ }^{f}$, Cesar I.P. Barrera ${ }^{f}$, Cemal Orhan ${ }^{g}$, Michael Volk ${ }^{a}$, Kazim Sahin ${ }^{g}$

aDrug Discovery Program, Reven Pharmaceuticals, Westminster, CO 80234, USA; fatih.uckun@reven.com (F.M.U) - https://orcid.org/0000-0001-9334-183X; cynthia.lee@reven.com (C.L); michael.volk@reven.com (M.V);

${ }^{b}$ Department of Developmental Therapeutics, Immunology, and Integrative Medicine, Ares Pharmaceuticals, St. Paul, MN 55110, USA; fatih.uckun@aresmit.com c/PRX Research and Dallas Regional Medical Center, Dallas, TX 75149, USA (M.S., M.A, A.S); msaeed@prxresearch.com (M.S); mawili@prxresearch.com_(M.A); ashibli@prxresearch.com dDepartment of Pathology Faculty of Medicine, Firat University, Elazig 23119, Turkey; ozercanih@firat.edu.tr (I.H.O).

eMemorial Hermann Memorial City Medical Center, Houston, TX 77024, USA and HD Research, Bellaire, TX 77401, USA (A.W.S); askolnick@ergclinical.com (A.W.S);

fUnited Memorial Medical Center, Houston, TX 77091, USA (J.V.,A.P, C.B.); josephvaron@yahoo.com (J.V); aprusmack@lfros.com (A.P), cbarrera@ummc.care (C.B)

9Department of Animal Nutrition, Faculty of Veterinary, Firat University, Elazig 23119, Turkey; corhan@firat.edu.tr (CO) and ksahin@firat.edu.tr (K.S.)

\section{ABSTRACT}

Background. The identification of effective strategies capable of reducing the case mortality rate of high-risk COVID-19 is an urgent and unmet medical need. We recently reported the clinical safety profile of RJX, a well-defined intravenous GMP-grade pharmaceutical formulation of antioxidant and anti-inflammatory vitamins as active ingredients, in a Phase 1 study in healthy volunteers (ClinicalTrials.gov Identifier: NCT03680105) (Uckun et al., Front. Pharmacol. 11, 594321. 10.3389/fphar.2020.594321). Here we report data from a pilot clinical study (RPI-015) which examined the safety, tolerability, and feasibility of using RJX in combination with clinical standard of care (SOC) in hospitalized COVID-19 patients with pneumonia (ClinicalTrials.gov

NOTE: This preprint reports new research that has not been certified by peer review and should not be used to guide clinical practice. 1 
Identifier: NCT04708340). In addition to our early clinical proof of concept (POC) data, we also present non-clinical POC from a mouse model of CRS and ARDS that informed the design of the reported clinical study.

Methods. 13 patients, who were hospitalized with COVID-19 pneumonia and abnormally elevated serum inflammatory biomarkers markers $\geq 3$ months prior to the identification of the first confirmed U.S case of the Omicron variant, were treated with IV RJX (daily $x 7$ days) plus SOC. Non-clinical POC study examined the ability of RJX plus dexamethasone (DEX) to improve the survival outcome in the lipopolysaccharide (LPS)-Galactosamine (GalN) mouse model of fatal cytokine release syndrome (CRS), sepsis and acute respiratory distress syndrome (ARDS).

Findings. In the Phase 1 clinical study, none of the 13 patients developed a treatment-related DLT, SAE, or Grade 3-5 AEs. Nine (9) of the 12 evaluable patients, including 3 patients with hypoxemic respiratory failure, showed rapid clinical recovery. In the non-clinical POC study in LPS-GalN challenged mice, the combination of RJX plus DEX was more effective than RJX alone or DEX alone, reversed the CRS as well as inflammatory tissue damage in the lungs and liver, and improved the survival outcome. Taken together, these findings provide the early clinical and non-clinical POC for the development of RJX as an adjunct to the SOC in the multi-modality management of high-risk COVID-19.

Keywords: COVID-19, RJX, Pharmacology, Pharmacodynamics, Vitamins, Nutrients, Nutraceuticals, Inflammation, Translational

*Correspondence: fatih.uckun@aresmit.com

\section{Introduction}

COVID-19 has a high fatality rate in elderly and high-risk populations with comorbidities, such as hypertension, diabetes, obesity, immunodeficiencies and hematologic cancers [1-12]. Several pro-inflammatory cytokines, including interleukin-1 (IL-1), interleukin-6 (IL6), tumor necrosis factor-alpha (TNF- $\alpha$ ), and transforming growth factor-beta (TGF- $\beta$ ), contribute to the development of a potentially fatal severe systemic inflammation in high-risk COVD-19 patients, which is known as cytokine release syndrome (CRS) and is often associated with acute lung injury (ALI) leading to ARDS and potentially multi-organ dysfunction (MOD) in rapid progression [13-23]. A 40\% likelihood of progression to severe-critical disease and ARDS within 10 days 
after symptom onset has been reported for high-risk COVID-19 patients [24-26] The identification of effective strategies capable of preventing the development of potentially fatal viral sepsis, cytokine release syndrome (CRS) and ARDS in high-risk COVID-19 patients, is an urgent and unmet medical need.

Rejuveinix $(\mathrm{RJX})$ is a formulation of several anti-inflammatory and anti-oxidant vitamins [26--34]. RJX exhibited promising single-agent anti-inflammatory activity in a mouse model of fatal CRS and ARDS [26]. Preliminary evidence suggested that it may effectively reverse CRS and ARDS if administered after the onset of ALI in LPS-GalN challenged mice [35]. Further, RJX showed a very favorable clinical safety and pharmacokinetics (PK) profile in a recently completed randomized, double-blind, placebo-controlled Phase I ascending dose-escalation study in healthy volunteers (ClinicalTrials.gov Identifier: NCT03680105) [26].

Here we report data from a pilot clinical study which examined the safety, tolerability, and feasibility of using RJX in combination with clinical standard of care (SOC), including low dose Dexamethasone (DEX) (or Solumedrol) in hospitalized COVID-19 patients with pneumonia (ClinicalTrials.gov Identifier: NCT04708340). All patients were enrolled $\geq 3$ months prior to the identification of the first confirmed U.S case of the Omicron variant. In addition to our early clinical proof of concept (POC) data, we also present non-clinical POC from a mouse model of CRS and ARDS that informed the design of the reported pilot clinical study. In the clinical study, no patient developed a treatment-related DLT, SAE, or Grade 3-5 AEs. Seventy-five \% of patients showed rapid clinical recovery with resolution of the hyperinflammatory response and oxygen therapy requirements. In the non-clinical POC study in LPS-GalN challenged mice, the combination of RJX plus DEX was more effective than RJX alone or DEX alone, reversed the sepsis-associated CRS as well as inflammatory tissue damage in the lungs and liver, and improved the survival outcome. Taken together, these findings provide the early clinical and non-clinical POC for the development of RJX as an adjunct to the SOC in the multi-modality management of severe COVID-19 patients with viral sepsis and indicate its clinical impact potential.

\section{Materials and methods}

\section{Rejuveinix (RJX)}

RJX is a GMP-grade pharmaceutical composition of anti-inflammatory and anti-oxidant vitamins (Table S1 and Supplemental Methods) [26,36]. 


\section{Study Design and Eligibility Criteria}

The safety, tolerability, and feasibility of using RJX in combination with clinical standard of care for hospitalized COVID-19 patients were evaluated in an open-label pilot study that was Part 1 of an ongoing double-blind, randomized, Phase $1 / 2$ Study (ClinicalTrials.gov Identifier: NCT04708340). 13 patients who were hospitalized with COVID-19 pneumonia and abnormally elevated serum inflammatory biomarkers markers were with IV RJX (daily $x 7$ days) plus SOC. All patients were enrolled between April 5, 2021, and September 1, 2021, prior to the identification of the first case of the Omicron variant on December 1, 2021. The follow-up was complete through December 9, 2021. The primary goal of the study was to evaluate the safety and tolerability of RJX plus SOC in hospitalized severe COVID-19 patients. The secondary goal was to evaluate the clinical efficacy of RJX plus SOC in hospitalized severe COVID-19 patients. The Eligibility Criteria are detailed in the clinical protocol synopsis posted at ClinicalTrials.gov ((ClinicalTrials.gov Identifier: NCT04708340). Patients received daily $40 \mathrm{~min}$ ( $\pm 10 \mathrm{~min}$ ) infusions of $20 \mathrm{~mL}$ RJX mixed with $100 \mathrm{~mL}$ normal saline (total volume $=120 \mathrm{~mL}$ ) intravenously plus SOC for 7 consecutive days. Some patients who no longer required inpatient care due to rapid improvement of their medical condition were discharged before day 7 and consequently received fewer than 7 treatments of RJX. SOC was provided until the patient was discharged. AEs were graded according to National Cancer Institute (NCl) Common Terminology Criteria for Adverse Events Version 5.0 ( $\mathrm{NCl}$ CTCAE (v5.0). An 8-point ordinal scale was used as an assessment of the clinical status at the first assessment of a given study day (Supplemental Methods).

\section{Study Conduct}

The study was performed under IND149585 at the following 4 centers in the US as an open-label study sponsored by Reven Pharmaceuticals: (1) Memorial Hermann Memorial City Medical Center, Houston, Texas; (2) Christus Health Santa Rosa Hospital, New Braunfels, Texas; (3) LFROS Research and United Memorial Medical Center, Houston, Texas; (4) PRX Research and Dallas Regional Medical Center, Dallas, Texas.

\section{Patient Disposition and Patient Characteristics}

Twenty-one patients were screened for the clinical study. The details of patient disposition are shown in Figure S1. There were 8 screen failures. Thirteen hospitalized adult patients with 
medRxiv preprint doi: https://doi.org/10.1101/2022.02.12.22270748; this version posted February 18, 2022. The copyright holder for this preprint (which was not certified by peer review) is the author/funder, who has granted medRxiv a license to display the preprint in perpetuity.

All rights reserved. No reuse allowed without permission.

severe or critical COVID-19, including 8 males and 5 females with a median age of 46 years (Range: 24-72 years) of whom 11 were White (Hispanic or Latino) and 2 were Asian (not Hispanic or Latino) were enrolled in one of the 2 cohorts of the clinical study within 0-11 days (Median: 4 days; Mean \pm SE $=4.5 \pm 1.0$ ) days after initial COVID-19 diagnosis (Table S2). All 13 patients had imaging evidence of viral pneumonia and they were hypoxic requiring oxygen therapy. All patients were symptomatic with cough and shortness of breath. Nine patients had a fever as well. The mean and median BMI values were 35.6 \pm 1.9 and 35.1, respectively (Range: 23.8-49.4). Ten patients were obese with BMI values ranging from 32.1 to 49.4 and 2 patients were overweight with BMI values of 28.3 and 29.3, respectively. Five patients had HTN, 3 patients had diabetes, and 3 patients had pulmonary co-morbidities (asthma or COPD). Only one patient was vaccinated. All 13 patients had elevated serum CRP values ranging from 42.4 to 297.6 (Median: 64.3; Mean \pm SE $=91.8 \pm 19.1$ ). The ALC values ranged from 0.3 to 1.4 (Median: 0.9; Mean \pm $\mathrm{SE}=0.8 \pm 0.1$ ). Eleven patients had lymphocytopenia with $\mathrm{ALC}<1,000 / \mu \mathrm{L}$. All 6 patients treated in Cohort 1 had severe COVID-19 with Chest X-ray/CT-documented pneumonia associated with hypoxemia and respiratory distress, elevated baseline levels of inflammation markers in blood, such as abnormally high levels of CRP, IL-6, Ferritin, and/or LDH, and had a baseline score of 4 based on the 8-point ordinal scale (Table S2). By comparison, all 7 patients treated in Cohort 2 had critical COVID-19 with Chest X-ray/CT-documented pneumonia associated with hypoxemic respiratory failure requiring high flow oxygen therapy and/or non-invasive positive pressure ventilation (NIPPV), increased inflammation markers and had a baseline score of 3 based on the 8-point ordinal scale (Table S2). One Cohort 2 patient withdrew consent on day 4 and was replaced with a new patient to have a total of 6 patients evaluable for response.

\section{Ethics Statement and Study Approval}

The study was performed according to the guidelines of the International Conference on Harmonization (ICH) for Good Clinical Practice (ICHE6/GCP). A written informed consent was obtained from patients prior to enrollment. The study protocol was approved by the WCG-Central Institutional Review Board (IRB) (OHRP/FDA Parent Organization number: IORG0000432; OHRP/FDA IRB registration number: IRB00000533). The Central IRB-approved study/protocol number was RPI015 (IRB Tracking Number: 20203418).

\section{Statistical Analyses of Clinical Data}


Standard statistical methods were applied. Descriptive statics for patient cohorts were calculated using the $\mathrm{R}$ platform ( $\mathrm{R}$ version 4.1 .2 (2021-11-01)) ran in Rstudio (2021.09.0 Build 351) using standard functions provided by the statistical package "plyr_1.8.6". Swimmer plots to visualize individual patient treatment outcomes and waterfall plots to visualize grouped and ranked outcomes were constructed using graph drawing packages implemented in the $R$ programming environment: swimplot_1.2.0, colorspace_2.0-2, ggplot2_3.3.5, ggbreak_0.0.7, cowplot_1.1.1, ggh4x_0.2.1 and ggthemes_4.2.4. The Kaplan-Meier method was used to investigate the survival of patients utilizing software packages survival_3.2-13, survminer_0.4.9 and survMisc_0.5.5 in R environment. The kinetics of the CRS-related serum biomarkers were investigated using first-order exponential "decay" functions of percentage of each biomarker. The combined results for each biomarker were graphed on semi-log axis $\left(\log _{10}(\%\right.$ inhibition$)=$ slope $x$ Time + Intercept). The time to $50 \%$ reduction of the serum concentration of each biomarker was calculated from the intercept and the slope of the decay function $\left(\left(\log _{10}(50)-\right.\right.$ Intercept)/slope). These operations were carried out in the $\mathrm{R}$ programming environment: plyr_1.8.6 and ggplot2_3.3.5.

\section{LPS-GalN model of fatal cytokine storm and sepsis}

The therapeutic activities of RJX, DEX, and RJX plus DEX were compared side by side in the LPS-GalN model of fatal CRS, sepsis and ARDS using male BALB/c mice, as previously described [26]. The RJX doses were $0.7 \mathrm{~mL} / \mathrm{kg}(\sim 14 \mu \mathrm{L} / 20 \mathrm{~g}$ mouse $)$ and $1.4 \mathrm{~mL} / \mathrm{kg}(\sim 28 \mu \mathrm{L} / 20$ $\mathrm{g} /$ mouse), and they were administered as intraperitoneal bolus injections. The doses of the active ingredients at the $0.7 \mathrm{~mL} / \mathrm{kg}$ dose were $31.5 \mathrm{mg} / \mathrm{kg}$ Vitamin C, $2.2 \mathrm{mg} / \mathrm{kg}$ Vitamin B1, $0.09 \mathrm{mg} / \mathrm{kg}$ Vitamin B2, $4.2 \mathrm{mg} / \mathrm{kg}$ Vitamin B3, $0.1 \mathrm{mg} / \mathrm{kg}$ Vitamin B5, $4.2 \mathrm{mg} / \mathrm{kg}$ Vitamin B6, $0.07 \mathrm{mg} / \mathrm{kg}$ Vitamin B12, and $28.3 \mathrm{mg} / \mathrm{kg}$ magnesium sulfate. The doses for the active ingredients at the 1.4 $\mathrm{mL} / \mathrm{kg}$ dose were $63 \mathrm{mg} / \mathrm{kg}$ Vitamin C, $4.4 \mathrm{mg} / \mathrm{kg}$ Vitamin B1, $0.18 \mathrm{mg} / \mathrm{kg}$ Vitamin B2, $8.4 \mathrm{mg} / \mathrm{kg}$ Vitamin B3, $0.2 \mathrm{mg} / \mathrm{kg}$ Vitamin B5, $8.4 \mathrm{mg} / \mathrm{kg}$ Vitamin B6, $0.14 \mathrm{mg} / \mathrm{kg}$ Vitamin B12, and $56.6 \mathrm{mg} / \mathrm{kg}$ magnesium sulfate [26]. These sub-MTD dose levels were based on the observation of singleagent activity in the LPS-GalN mouse model of sepsis [26]. $0.7 \mathrm{~mL} / \mathrm{kg}$ mouse dose corresponds to a human equivalent dose (HED) of $0.057 \mathrm{ml} / \mathrm{kg}$ of RJX, which is $7.5 \%$ of its MTD of $0.759 \mathrm{~mL} / \mathrm{kg}$ determined in the previously published randomized Phase 1 clinical trial in healthy volunteers [26]. The $1.4 \mathrm{~mL}$ per $\mathrm{kg}$ mouse dose corresponds to a human equivalent dose (HED) of 0.114 
medRxiv preprint doi: https://doi.org/10.1101/2022.02.12.22270748; this version posted February 18, 2022. The copyright holder for this preprint (which was not certified by peer review) is the author/funder, who has granted medRxiv a license to display the preprint in perpetuity. All rights reserved. No reuse allowed without permission.

$\mathrm{ml} / \mathrm{kg}$ of RJX, which is $15 \%$ of its MTD determined in the previously published randomized Phase 1 clinical trial in healthy volunteers.

The care and treatments of the animals were provided in accordance with the Guide for the Care and Use of Laboratory Animals. The study was approved by the Animal Care and Use Committee of Firat University (Number: 420629). Male BALB/c mice (6-8 weeks old and weighing on average $20 \mathrm{~g}$ ), which were purchased from Laboratory Animal Center of Firat University, were randomly divided into different treatment groups, as previously reported [26]. Mice were housed in cages throughout the study, and the following conditions were maintained: temperature, $22 \pm$ $2{ }^{\circ} \mathrm{C}$; relative humidity, $55 \pm 5 \%$; and a 12-h light: dark cycle. As in previous studies, we applied the concealment of treatment allocation and blind outcome assessment to reduce the risk of bias [26]. In order to induce fatal CRS and ARDS, mice were challenged with an i.p. injection of LPS plus D-galactosamine (Sigma, St. Louis, MO). Each mouse received a $500 \mu \mathrm{L}$ i.p. injection of LPS-GalN (consisting of $100 \mathrm{ng}$ of LPS plus $8 \mathrm{mg}$ of D-galactosamine). Treatments were delayed until 2 hours post-LPS-GalN injection when mice have a fulminant systemic inflammation with very severe lung and liver damage as well as markedly elevated inflammatory cytokine levels. Vehicle control mice were treated with $0.5 \mathrm{~mL}$ NS instead of RJX. NS was administered i.p 2 hours after LPS-GalN. Test mice received either RJX $(0.7 \mathrm{ml} / \mathrm{kg}$ or $1.4 \mathrm{ml} / \mathrm{kg})$ or DEX $(0.1 \mathrm{mg} / \mathrm{kg}$, $0.6 \mathrm{mg} / \mathrm{kg}$ or $6.0 \mathrm{mg} / \mathrm{kg}$ ) as a monotherapy in a side-by-side comparison. We also examined a combination of $0.7 \mathrm{~mL} / \mathrm{kg}$ RJX with either $0.6 \mathrm{mg} / \mathrm{kg}$ or $6 \mathrm{mg} / \mathrm{kg}$ DEX at 2 hours post-LPS-GalN injection. Drugs were administered i.p. in a total volume of $0.5 \mathrm{ml}$. The human equivalent dose (HED) levels were determined as described [37]. Tissue levels of oxidative stress biomarkers superoxide dismutase (SOD), catalase (CAT) and glutathione peroxidase (GSH-Px), ascorbic acid levels, and malondialdehyde (MDA) were determined to examine the effects of RJX, DEX, and RJX + DEX on the sepsis-associated oxidative stress. Levels of Interleukin 6 (IL-6) and tumor necrosis factor-alpha (TNF- $\alpha$ ) in serum samples were measured by quantitative ELISA using the commercially available Quantikine ELISA kits, as previously reported [26]. At the time of death, blood samples were obtained for biomarker studies. In addition, lungs and liver were harvested, fixed in $10 \%$ buffered formalin, and processed for histopathologic examination. $3 \mu \mathrm{m}$ sections were cut, deparaffinized, dehydrated, and stained with hematoxylin and eosin (H \& E) and examined with light microscopy using a digital image capture camera by an experienced histopathologist who was blind to the study groups.

\section{Statistical analysis of Non-Clinical Data}


Statistical analyses were performed using standard methods and the SPSS statistical program (IBM, SPPS Version 21), as previously reported [26]. P-values $<0.05$ were considered significant.

\section{Results}

\section{Non-clinical Proof of Concept Data Supporting the Use of RJX Alone and In Combination} with DEX for Treatment of Severe COVID-19

LPS-GaIN-challenged mice experience a rapid onset systemic inflammation with markedly elevated inflammatory cytokine levels as well as severe lung injury, reminiscent of severe COVID19 , as early as 2 hours after the administration of LPS-GalN [26]. A single low dose RJX at the assigned low dose levels of $0.7 \mathrm{ml} / \mathrm{kg}$ (HED: $0.057 \mathrm{ml} / \mathrm{kg} ; 7.5 \%$ of human MTD) delivering 31.5 $\mathrm{mg} / \mathrm{kg}$ Vitamin C, $2.2 \mathrm{mg} / \mathrm{kg}$ Vitamin B1, $0.09 \mathrm{mg} / \mathrm{kg}$ Vitamin B2, $4.2 \mathrm{mg} / \mathrm{kg}$ Vitamin B3, $0.1 \mathrm{mg} / \mathrm{kg}$ Vitamin B5, $4.2 \mathrm{mg} / \mathrm{kg}$ Vitamin B6, $0.07 \mathrm{mg} / \mathrm{kg}$ Vitamin B12, and $28.3 \mathrm{mg} / \mathrm{kg}$ magnesium sulfate) and $1.4 \mathrm{ml} / \mathrm{kg}$ (HED: $0.114 \mathrm{ml} / \mathrm{kg} ; 15 \%$ of human MTD) delivering $63 \mathrm{mg} / \mathrm{kg}$ Vitamin C, $4.4 \mathrm{mg} / \mathrm{kg}$ Vitamin B1, $0.18 \mathrm{mg} / \mathrm{kg}$ Vitamin B2, $8.4 \mathrm{mg} / \mathrm{kg}$ Vitamin B3, $0.2 \mathrm{mg} / \mathrm{kg}$ Vitamin B5, $8.4 \mathrm{mg} / \mathrm{kg}$ Vitamin B6, $0.14 \mathrm{mg} / \mathrm{kg}$ Vitamin B12, and $56.6 \mathrm{mg} / \mathrm{kg}$ magnesium sulfate, which was administered at $2 \mathrm{~h}$ after LPS-GalN injection, effectively reversed the LPS-GaIN induced increased serum levels of the pro-inflammatory cytokines IL-6 and TNF- $\alpha$ within $24 \mathrm{~h}$ (Supplemental Information, Figure S2). $1.4 \mathrm{ml} / \mathrm{kg}$ low dose (15\% of MTD) RJX was significantly more effective than a single DEX injection at standard $0.6 \mathrm{mg} / \mathrm{kg}$ dose level (HED: $0.05 \mathrm{mg} / \mathrm{kg} ; 4 \mathrm{mg}$ standard dose for an 80 $\mathrm{kg}$ person) and comparable to $6.0 \mathrm{mg} / \mathrm{kg}$ high dose DEX (HED: $0.49 \mathrm{mg} / \mathrm{kg}$; $39 \mathrm{mg}$ dose for an $80 \mathrm{~kg}$ person, which is higher than the standard 4-8 $\mathrm{mg}$ dose levels for DEX) (Figure S2). The observed reversal of the inflammatory cytokine response by RJX $(0.7$ or $1.4 \mathrm{~mL} / \mathrm{kg})$ or DEX $(0.6$ or $6.0 \mathrm{mg} / \mathrm{kg}$ ) was associated with a partial reversal of the lung and liver injury that was documented at $2 \mathrm{~h}$ post-LPS-GalN injection when treatments were initiated (Supplemental Information, Figure S3, Figure S4, Figure S5) as well as a significant improvement of the survival outcome in this LPS-GaIN model of otherwise invariably fatal CRS and ARDS (Supplemental Information, Figure S6). A combination of low dose $(0.7 \mathrm{ml} / \mathrm{kg}) \mathrm{RJX}$ and high dose $(6.0 \mathrm{mg} / \mathrm{kg})$ DEX effectively reversed the increased serum levels of the systemic inflammation markers (IL-6, TNF- $\alpha$, and LDH) within $24 \mathrm{~h}$, and appeared to be overall more effective than DEX alone or RJX alone (Figure S7). 
medRxiv preprint doi: https://doi.org/10.1101/2022.02.12.22270748; this version posted February 18, 2022. The copyright holder for this preprint (which was not certified by peer review) is the author/funder, who has granted medRxiv a license to display the preprint in perpetuity.

All rights reserved. No reuse allowed without permission.

LPS-GalN caused severe inflammation and oxidative stress in the lungs and liver with enhanced lipid peroxidation, as measured by a marked elevation of MDA levels, and decreased tissue levels of Vitamin $\mathrm{C}$ as well as the anti-oxidant enzymes GSH-Px that inhibits lipid peroxidation and SOD that converts superoxide anion radicals contributing to lipid peroxidation into hydrogen peroxide and oxygen. Low dose RJX alone or in combination with DEX significantly suppressed the oxidative stress, as documented by increases in Vitamin C, GSH-Px and SOD levels that were markedly reduced by LPS-GaIN (Figure S8). The tissue healing activity of the combination therapy in the lungs and liver was also more pronounced than the tissue healing activity of RJX alone or DEX alone (Figure S9, Figure S10). In contrast to the rapid death of all control mice treated with vehicle/normal saline (NS) (Median survival: $4.3 \mathrm{~h}$ post-LPS-GaIN or $2.3 \mathrm{~h}$ after administration of NS), 100\% of mice treated with low dose RJX + high dose DEX survived the LPS-GalN challenge (Median survival: $>24$ hours post LPS-GalN or $>22$ hours after initial administration of RJX+DEX) (Figure S11). By comparison, the combined group of mice treated with monotherapy (i.e., RJX alone or DEX alone) $(n=12)$ had a 24-hour survival rate of $41.7 \%$ (Monotherapy with RJX or DEX vs. Combination therapy with RJX+DEX: Log-rank $X^{2}=$ 3.053, $p=0.081)$.

We next evaluated the efficacy of a combination regimen that employs low dose RJX $(0.7$ $\mathrm{mL} / \mathrm{kg})$ plus standard dose $(0.6 \mathrm{mg} / \mathrm{kg})$ DEX. Notably, delayed treatments with low dose RJX plus standard dose DEX starting at $2 \mathrm{~h}$ after the LPS-GalN injection reversed the lung damage, as evidenced by significantly reduced histopathological lung scores (Figure 1). The tissue healing activity of the combination was more pronounced than the tissue healing activity of RJX alone or DEX alone (Figure 1A). Hence, although treatments were delayed until the onset of fulminant cytokine storm and systemic inflammation as well as very severe lung damage, a near-complete recovery of the inflammatory lung injury was achieved in the vast majority of mice within 24 hours. Similar to its effects on the LPS-GaIN induced ALI, RJX + DEX combination significantly reduced the liver injury (Figure 1B). While 5 of 10 mice (50\%) treated with standard dose DEX alone and 14 of 20 mice $(70 \%)$ treated with low dose RJX alone had severe residual lung injury (histopathological lung score $\geq 3$ ), only 2 of 20 mice $(10 \%)$ of mice treated with the DEX+RJX combination had severe residual lung damage. The observed superiority of the combination regimen was statistically significant (Figure 1C). Similarly, while 5 of 10 DEX treated mice (50\%) and 12 of 20 RJX treated mice (60\%) had severe residual liver damage, only 1 of 20 mice (10\%) treated with the DEX+RJX combination had severe residual liver damage and this difference was 
statistically significant (Figure 1C). In contrast to the rapid death of all control mice treated with NS (Median survival: $5.1 \mathrm{~h}$ post LPS-GalN or $3.1 \mathrm{~h}$ after administration of NS), 15 of 20 (75\%) of mice treated with RJX + DEX survived the LPS-GalN challenge (Median survival: > 24 h post LPSGaIN (Figure 2). By comparison, the combined group of mice treated with monotherapy (i.e., RJX alone or DEX alone) $(\mathrm{N}=30)$ had a $24-\mathrm{h}$ survival rate of $53 \%$ (i.e., 16 of 30 mice) (Monotherapy with RJX or DEX vs. Combination therapy with RJX+DEX: Log-rank $\left.X^{2}=3.977, p=0.046\right)$.

\section{Clinical Proof of Concept Data Supporting the Use of RJX in Combination with SOC for Treatment of Severe COVID-19}

Safety. All patients were enrolled $\geq 3$ months prior to the identification of the first confirmed U.S case of the Omicron variant. Patient characteristics and demographic features are shown in Table S2. All patients were treated daily with IV RJX plus institutional SOC (Table S3). One patient withdrew consent on day 4 without any treatment-emergent AEs. Table $\mathbf{S 4}$ details all Grade 3-5 AEs reported. No patient developed a DLT or SAE while still receiving RJX. None of the reported Grade 3-5 AEs was deemed related to RJX - they were all reported as related to COVID-19. Listing of all grade SAEs is provided in Table S5. Table S6 depicts the incidence of Grade 3-5 AEs and SAEs by MedDRA PT and listing of deaths for all enrolled patients.

Pharmacodynamics. Protocol therapy resulted in a rapid resolution of pneumonia and systemic inflammation in 9 of 12 patients enrolled. In these 9 patients, we observed a rapid normalization in the levels of the inflammation biomarkers CRP, Ferritin, LDH, and IL-6. We investigated the first order kinetics of the CRP decline in each of the 9 responding patients by fitting a straight line to a semi-log plot of the portion of the biomarker curve over the course of RJX treatment when a maximum reduction in values was observed. The slope of the line represents the rate constant for CRP reduction in $\log _{10}$ scale, and times to $50 \%$ reduction of CRP values were calculated using the rate constant (Figure 3). Serum CRP levels showed a rapid decline with an average (Mean \pm SE) time of $1.6 \pm 0.2$ days to reach $50 \%$ of baseline values (Median: 1.7 days, Range: 0.9-2.5 days) (Figure S12). Similar results were observed for IL-6 (N=5; Mean: $13.1 \pm 6.1$ days, Median: 6.3 days, Range: 1.6 - 29.3 days (Figure 4), Ferritin ( $\mathrm{N}=8$; Mean: $8.8 \pm$ 3.4 days, Median: 5.2 days, Range: 2.9 - 32.1 days) (Figure S13) and LDH (N=5; Mean: $8.6 \pm$ 1.8 days, Median: 7.2 days, Range: 4.9 - 14.6 days) levels (Figure S14). By comparison, the 
medRxiv preprint doi: https://doi.org/10.1101/2022.02.12.22270748; this version posted February 18, 2022. The copyright holder for this preprint (which was not certified by peer review) is the author/funder, who has granted medRxiv a license to display the preprint in perpetuity.

All rights reserved. No reuse allowed without permission.

kinetics of normalization of elevated TGF- $\beta$ levels was much slower and near-normal levels were achieved in some patients only after 1-2 months ( $N=4$; Mean $\pm S E: 26.6 \pm 17.3$ days; Median 13.2 days; Range: 2.3-77.6 days) (Figure S15).

Efficacy. The outcome data for 12 evaluable patients are shown in Table 1 (6 from Cohort 1 and 6 from Cohort 2; Patient 008-1204 who withdrew his consent on day 4 is not shown in this table). Nine (9) of the 12 patients, including each of the 6 Cohort 1 patients and 3 of 6 Cohort 2 patients with hypoxemic respiratory failure, showed rapid clinical recovery with normalization of the blood oxygen levels. The overall survival curve is shown in Figure 5; the median survival was not reached.

Figure 6 shows the kinetics of improvement or worsening of the clinical health status scores according to the 8-point ordinal scale for each patient. The score changes were charted utilizing Swimmer plots. Figure S16 shows a waterfall plot depicting the maximum increase (improvement) or decrease (worsening) of the 8-point Ordinal Scale scores. The score change ranged from -2 to +5 (Median: +3.5 ; Mean \pm SE: $2.4 \pm 0.8$ ). The score change for Cohort 1 patients $(\mathrm{N}=6)$ ranged from +3 to +4 (Median: +3.5 , Mean $\pm \mathrm{SE}: 3.5 \pm 0.2$ ). By comparison, the score change for Cohort 2 patients $(N=6)$ ranged from -2 to +5 (Median: +1 ; Mean $\pm S E$ :

$1.3 \pm 1.5)$. Each of the 6 patients in Cohort 1 had a baseline score of 4 . Their oxygen supplementation requirements have resolved, and they were consequently discharged from the hospital between 3 to 7 days (median: 4.5 days) after initiation of protocol therapy. Hence, their scores showed a +3 (Score 7: Not hospitalized, limitation on activities and/or requiring home oxygen) to +4 improvement within a week (Score 8: Not hospitalized, no limitations on activities - corresponds to ECOG score of 0 ). Of the 6 patients with hypoxemic respiratory failure who had a baseline score of 3 and required high flow oxygen and/or NIPPV, 3 were discharged from hospital at 7,7, and 14 days respectively upon resolution of their hypoxemic respiratory failure with a +4-+5 improvement on the 8-point ordinal scale (Figure 6). Two of the remaining 3 patients experienced progression of their COVID-19 requiring intubation on day 8 and one patient developed COVID-19 related complications, including sepsis with coagulopathy (day 1017), pulmonary embolism (day 19), and fatal mesenteric ischemia (day 23) (Figure 6, Table S6).

\section{Discussion}


medRxiv preprint doi: https://doi.org/10.1101/2022.02.12.22270748; this version posted February 18, 2022. The copyright holder for this preprint (which was not certified by peer review) is the author/funder, who has granted medRxiv a license to display the preprint in perpetuity. All rights reserved. No reuse allowed without permission.

Globally, COVID-19 now is a major cause of mortality [9, 37-41]. Patients with high-risk COVID-19 with viral sepsis are in urgent need of effective strategies that can prevent and/or reverse the systemic inflammatory process and its complications, including acute respiratory distress syndrome (ARDS) and multi-organ failure [42-53]. Here we report a pilot clinical study of RJX plus standard of care in hospitalized COVID-19 patients with pneumonia $\geq 3$ months prior to the identification of the first confirmed U.S case of the Omicron COVID-19 variant, which extends the preclinical observations in a mouse model of fatal ARDS and provides promising early clinical proof of concept data for developing RJX as part of the multi-modality treatment strategies against severe COVID-19.

DEX has been shown to improve the survival outcome of patients with ARDS [53-60]. Furthermore, recent clinical studies, including the open-label randomized "RECOVERY" trial, have demonstrated that the standard anti-inflammatory drug DEX improves the clinical course and treatment outcome of hospitalized high-risk COVID-19 patients [54-57] Rees et al. reported that DEX reduced the death rate by one third in patients on a ventilator and by one fifth in patients on oxygen support [55]. Early findings showed that DEX decreased the mortality risk from $40 \%$ to $28 \%$ in ventilated patients and $25 \%-20 \%$ for COVID-19 patients on oxygen therapy over 28 days [57]. COVID-19 patients with moderate or severe ARDS who were treated with DEX plus SOC had significantly more ventilator-free days over 28 days than the reference group treated with SOC alone [58].

IL-1, IL-6, TNF- $\alpha$, and TGF- $\beta$ are important pro-inflammatory cytokines that contribute to the pathophysiology of the cytokine release syndrome (CRS), ARDS and multi-organ failure in critically sick adult COVID-19 patients with viral sepsis [13-23] as well as children and adolescents with COVID-19 who develop a multi-system inflammatory syndrome (MIS-C) [59-62]. Recently, we demonstrated that RJX prevents in the LPS-GalN mouse model of sepsis the marked increase of each of these cytokines in the serum as well as lungs and liver [26]. Furthermore, preliminary evidence suggested that it may also be effective in reversing sepsis if administered after the onset of sepsis [35].

The primary objective of the non-clinical proof-of-concept study was to compare the effects of RJX, DEX, and their combination on the severity of CRS and survival outcome in an animal model that employs LPS-GalN to induce fatal sepsis, CRS, ARDS. We hypothesized that RJX, especially when combined with DEX, would improve the survival outcome of mice who develop systemic inflammation following injection with a lethal dose of LPS-GaIN. The experimental data 
medRxiv preprint doi: https://doi.org/10.1101/2022.02.12.22270748; this version posted February 18, 2022. The copyright holder for this preprint (which was not certified by peer review) is the author/funder, who has granted medRxiv a license to display the preprint in perpetuity.

All rights reserved. No reuse allowed without permission.

demonstrate that RJX - at a dose level >10-times lower than its clinical MTD - exhibits potent single-agent anti-inflammatory activity and is as effective as DEX at standard dose levels in this model of fatal sepsis. The combination of RJX plus DEX immediately and profoundly decreased the inflammatory cytokine responses to LPS-GaIN, mitigated the inflammatory tissue damage in the lungs and liver, and prevented a fatal outcome. Although the treatments were started after the onset of fulminant cytokine storm characterized by markedly elevated serum cytokine levels and systemic inflammation as well as severe lung damage, a near-complete recovery of the inflammatory lung injury was achieved within 24 hours, and the survival outcome was improved. The superiority of the combination regimen was particularly striking when we compared the histopathological data on sepsis-associated organ damage in lungs and liver from mice treated with monotherapy (RJX or DEX alone) vs. combination therapy. Notably, initiation of combination therapy after onset of the inflammatory cytokine responses and systemic inflammation resulted within 24 hours in a near-complete recovery of very severe organ damage in the lungs that was caused by LPS-GaIN induced sepsis. These findings provide the preclinical proof of concept for the clinical development of RJX as an adjunct of the standard of care in the multi-modality management of sepsis and its complications.

Several monoclonal antibodies that serve as inhibitors of the receptors and/or signaling pathways activated by specific pro-inflammatory cytokines are being developed and evaluated as anti-inflammatory drug candidates for prevention of CRS-related complications of severe COVID19, including but not limited to the IL-1 receptor antagonist Anakinra (Kineret), IL-6 receptor antagonist tocilizumab (Actemra), TNF- $\alpha$ inhibitor infliximab (Remicade) [14,15,22,42,49-52]. A major potential advantage of RJX versus biotherapeutic agents such as monoclonal antibodies that inhibit specific cytokine pathways is its ability to inhibit multiple pathways combined with its low cost of production which should make it readily available in low- to middle-income countries and therefore its further development and assessment as a potential COVID-19 drug candidate has potential global relevance.

RJX is hoped to reduce the case mortality rate of severe COVID-19 by accelerating the resolution of the systemic and pulmonary inflammatory process. Here we showed that 9 of the 12 patients, including 3 patients with hypoxemic respiratory failure, showed rapid clinical recovery with resolution of the hyperinflammatory response and oxygen therapy requirements. This early clinical experience with RJX in 12 hospitalized patients with severe-critical COVID-19 warrants further investigation of its clinical impact potential. We hypothesize that the addition of RJX to a 
standard of care, including DEX, will shorten the time to clinical resolution of the cytokinemediated multi-system inflammatory process and thereby mitigate the inflammatory organ injury. RJX has no steroids, and it contains niacinamide, pyridoxine, cyanocobalamin and Mg-sulfate in addition to ascorbic acid and thiamine. Additional studies in a randomized setting are needed to confirm the reported preliminary findings and assess any potential benefit from the addition of RJX to the SOC. RJX is currently being evaluated for its clinical impact potential as a component of multi-modality treatment algorithms for severe to critical COVID-19 in a placebo-controlled randomized Phase II study (ClinicalTrials.gov Identifier: NCT04708340). The randomized trial will test the hypothesis that RJX will contribute to a faster resolution of HRF when combined with DEX and other components of the standard of care.

\section{Data availability}

The original contributions presented in the study are included in the article/Supplementary Material. Further inquiries can be directed to the corresponding author.

Permission to reproduce material from other sources: Not applicable

\section{Ethics Statement and Study Approval}

The clinical study protocol was approved by the WCG-Central Institutional Review Board (IRB) (OHRP/FDA Parent Organization number: IORG0000432; OHRP/FDA IRB registration number: IRB00000533). The Central IRB-approved study/protocol number was RPI015 (IRB Tracking Number: 20203418). The study was performed in compliance with the International Conference on Harmonization (ICH) guidelines for Good Clinical Practice (ICHE6/GCP). Each patient provided a written informed consent (ICF) prior to enrollment.

The non-clinical research project was approved by the Animal Care and Use Committee of Firat University (Project No. 03092020-391-047; Ethics Committee Number: 420629).

\section{Funding Statement}

This study was funded by Reven Pharmaceuticals, LLC, a wholly-owned subsidiary of Reven Holdings Inc.

\section{Role of the Funder/Sponsor}


The sponsor did not participate in the collection of data. The funder had the following involvement with the study: 1. Provided funding to clinical research organizations for the operationalization of the study by clinical monitoring, medical monitoring, pharmacovigilance, and data management; 2 . Provided site awards to the investigative sites to compensate the sites for their clinical research expenses; and 3. Sponsored the IND, funded the regulatory affairs and quality assurance activities to ensure ICH/GCP compliance. The sponsor did not participate in the safety or efficacy assessments of the investigators. Among the authors, FMU and CL who participated in the analysis and decision to submit the manuscript for publication were consultants of Reven Pharmaceuticals.

\section{Conflict of Interest Statement}

Author FMU is employed by Ares Pharmaceuticals, and he serves as a consultant for Reven Pharmaceuticals. Author CL is employed by Oncotelic Therapeutics, and she serves as a consultant to Reven Pharmaceuticals. All authors declare no other competing interests.

\section{Author Contributions.}

Each author has made significant and substantive contributions to the study, reviewed and revised the manuscript, provided final approval for submission of the final version. F.M.U conceived the study, designed the evaluations reported in this paper, directed the data compilation and analysis, analyzed the data, and prepared the initial draft of the manuscript. K.S. directed the non-clinical study. K.S. and C.O. collected the non-clinical data and performed their analysis. I.H.O. performed the necropsies and histopathologic examinations on mice. M.A., A.S., A.W.S, J.V assisted in clinical study design, served as site investigators, screened and recruited participants, administered treatments, assessed adverse events and disease responses, collected safety and efficacy data, met regularly to review study data during the study, and reviewed the manuscript; F.M.U., S.Q., and C.L. analyzed and validated clinical data, performed statistical analyses.

\section{Acknowledgments}

The authors thank the patients who participated in this trial and their families, the coinvestigators, nurses, and study coordinators at each of the participating sites. The study was performed at the following centers in the US as an open-label study sponsored by Reven 
Pharmaceuticals: (1) Memorial Hermann Memorial City Medical Center, Houston, Texas; (2) Christus Health Santa Rosa Hospital, New Braunfels, Texas; (3) United Memorial Medical Center, Houston, Texas; (4) PRX Research and Dallas Regional Medical Center, Dallas, Texas.

This study was sponsored by Reven Pharmaceuticals, which provided RJX. We thank the Reven team members for their contributions to clinical operations, quality assurance, and IP/vendor management.

\section{References}

1. Huang, C., Wang, Y., Li, X., Ren, L., Zhao, J., Hu, Y., et al. (2020). Clinical features of patients infected with 2019 novel coronavirus in Wuhan, China. Lancet 395, 497-506. doi: 10.1016/S0140-6736(20)30183-5

2. Young, B. E., Ong, S. W. X., Kalimuddin, S., Low, J. G., Tan, S. Y., Loh, J., et al. (2020). Singapore 2019 Novel Coronavirus Outbreak Research Team. Epidemiologic Features and Clinical Course of Patients Infected With SARS-CoV-2 in Singapore. JAMA 323 (15), 14881494. doi : 10.1001/jama.2020.3204

3. Chen G, Wu D, Guo W, et al. Clinical and immunological features of severe and moderate coronavirus disease 2019. J Clin Invest 130: 2620-2629 (2020).

20. Moore J, June C. Cytokine release syndrome in severe COVID-19. Science 368: 473-474 (2020).

4. Lee LYW, Cazier J-B, Starkey T, Briggs SEW, Arnold R, Bisht V, et al. COVID-19 prevalence and mortality in patients with cancer and the effect of primary tumour subtype and patient demographics: a prospective cohort study. The Lancet Oncology. 2020;21(10):1309-16. 5. Lee LY, Cazier J-B, Angelis V, Arnold R, Bisht V, Campton NA, et al. COVID-19 mortality in patients with cancer on chemotherapy or other anticancer treatments: a prospective cohort study. Lancet (London, England). 2020;395(10241):1919-26.

6. Zheng Z., Peng F., Xu B., Zhao J., Liu H., Peng J., et al. (2020). Risk factors of critical and mortal COVID-19 cases: a systematic literature review and meta-analysis. J. Infect. 81 (2), e16e25. 10.1016/j.jinf.2020.04.021 [PMC free article] [PubMed] [CrossRef] [Google Scholar] 7. Zhou F., Yu T., Du R., Fan G., Liu Y., Liu Z., et al. (2020). Clinical course and risk factors for mortality of adult inpatients with COVID-19 in Wuhan, China: a retrospective cohort 
study. Lancet 395, 1054-1062. 10.1016/S0140-6736(20)30566-3 [PMC free article] [PubMed] [CrossRef] [Google Scholar]

8. Woolf S. H., Chapman D. A., Sabo R. T., Weinberger D. M., Hill L., Taylor D. D. H. (2020). Excess deaths from COVID-19 and other causes, March-July 2020. JAMA 324 (15), 1562-1564. 10.1001/jama.2020.19545 [PMC free article] [PubMed] [CrossRef] [Google Scholar] 9. Woolf S. H., Chapman D. A., Lee J. H. (2021). COVID-19 as the leading cause of death in the United States. Jama 325 (2), 123-124. 10.1001/jama.2020.24865 [PMC free article] [PubMed] [CrossRef] [Google Scholar]

10. Wu C., Chen X., Cai Y., Xia J., Zhou X., Xu S., et al. (2020). Risk factors associated with acute respiratory distress syndrome and death in patients with coronavirus disease 2019 pneumonia in Wuhan, China. JAMA Internal Med 180 (7), 934-943.

10.1001/jamainternmed.2020.0994 [PMC free article] [PubMed] [CrossRef] [Google Scholar] 11. Uckun F. M. (2020a). Prognostic factors associated with high-risk for fatal ARDS in COVID19 and potential role for precision Medicines as part of COVID-19 supportive care algorithms. Ann. Pulm. Crit. Care Med. 3 (2), 1-4. [Google Scholar] 12. Faust J. S., Krumholz H. M., Du C., Mayes K. D., Lin Z., Gilman C., et al. (2021). All-cause excess mortality and COVID-19-related mortality among US adults aged 25-44 Years, Marchjuly 2020. JAMA 325 (8), 785-787. 10.1001/jama.2020.24243 [PMC free article] [PubMed] [CrossRef] [Google Scholar]

13. Pasrija R, Naime M. The deregulated immune reaction and cytokines release storm (CRS) in COVID-19 disease. Int Immunopharmacol. 2021 Jan;90:107225. doi:

10.1016/j.intimp.2020.107225. Epub 2020 Nov 27. PMID: 33302033; PMCID: PMC7691139. 14. Conti P, Caraffa A, Gallenga CE, Ross R, Kritas SK, Frydas I, Younes A, Ronconi G. Coronavirus-19 (SARS-CoV-2) induces acute severe lung inflammation via IL-1 causing cytokine storm in COVID-19: a promising inhibitory strategy. J Biol Regul Homeost Agents. 2020 Nov-Dec;34(6):1971-1975. doi: 10.23812/20-1-E. PMID: 33016027.

15. Khadke S, Ahmed N, Ahmed N, Ratts R, Raju S, Gallogly M, de Lima M, Sohail MR. Harnessing the immune system to overcome cytokine storm and reduce viral load in COVID-19: a review of the phases of illness and therapeutic agents. Virol J. 2020 Oct 15;17(1):154. doi: 10.1186/s12985-020-01415-w. PMID: 33059711; PMCID: PMC7558250. 16. McGonagle D, Sharif K, O'Regan A, Bridgewood C. The Role of Cytokines including Interleukin-6 in COVID-19 induced Pneumonia and Macrophage Activation Syndrome-Like 
Disease. Autoimmun Rev. 2020 Jun;19(6):102537. doi: 10.1016/j.autrev.2020.102537. Epub 2020 Apr 3.

17. Berlin DA, Gulick RM, Martinez FJ. Severe Covid-19. N Engl J Med. 2020 Dec 17;383(25):2451-2460. doi: 10.1056/NEJMcp2009575. Epub 2020 May 15. PMID: 32412710. 18. Li X, Ma X. Acute respiratory failure in COVID-19: is it "typical" ARDS? Crit Care. 2020 May 6;24(1):198. doi: 10.1186/s13054-020-02911-9.

19. Torres Acosta MA, Singer BD. Pathogenesis of COVID-19-induced ARDS: implications for an ageing population. Eur Respir J. 2020 Sep 24;56(3):2002049. doi: 10.1183/13993003.020492020. PMID: 32747391; PMCID: PMC7397945.

21. Montenegro F, Unigarro L, Paredes G, Moya T, Romero A, Torres L, López JC, González FEJ, Del Pozo G, López-Cortés A, Diaz AM, Vasconez E, Cevallos-Robalino D, Lister A, OrtizPrado E. Acute respiratory distress syndrome (ARDS) caused by the novel coronavirus disease (COVID-19): a practical comprehensive literature review. Expert Rev Respir Med. 2021 Feb;15(2):183-195. doi: 10.1080/17476348.2020.1820329.

22. Tan LY, Komarasamy TV, Rmt Balasubramaniam V. Hyperinflammatory Immune Response and COVID-19: A Double-Edged Sword. Front Immunol. 2021 Sep 30;12:742941. doi: 10.3389/fimmu.2021.742941. PMID: 34659238; PMCID: PMC8515020. 23. H. Li, L. Liu, D. Zhang, J. Xu, H. Dai, N. Tang, X. Su, B. Cao, SARS-CoV-2 and viral sepsis: observations and hypotheses, Lancet. 395 (2020) 1517-1520. https://doi.org/10.1016/S01406736(20)30920-X.

24. Bi, Q., Hong, C., Meng, J., Wu, Z., Zhou, P., Ye, C., et al. (2020). Characterizing clinical progression of COVID-19 among patients in Shenzhen, China: an observational cohort study. medRxiv doi:10.1101/2020.04.22.20076190

25. Gold, J. A. W., Wong, K. K., Szablewski, C. M., Patel, P. R., Rossow, J., da Silva, J., et al. (2020). Characteristics and clinical outcomes of adult patients hospitalized with COVID-19 Georgia, March 2020. MMWR Morb. Mortal. Wkly. Rep. 69 (18), 545-550. doi:10.15585/mmwr.mm6918e1

26. Uckun F. M., Carlson J., Orhan C., Powell J., Pizzimenti N. M., Van Wyk H., et al. (2020a). Rejuveinix shows a favorable clinical safety profile in human subjects and exhibits potent preclinical protective activity in the Lipopolysaccharide-galactosamine Mouse model of acute respiratory distress syndrome and multi-organ failure. Front. Pharmacol. 11, 594321. 10.3389/fphar.2020.594321 [PMC free article] [PubMed] [CrossRef] [Google Scholar] 
27. Fowler AA, 3rd, Truwit JD, Hite RD, Morris PE, DeWilde C, Priday A, Fisher B, Thacker LR, 2nd, Natarajan R, Brophy DF, et al. Effect of vitamin C infusion on organ failure and biomarkers of inflammation and vascular injury in patients with sepsis and severe acute respiratory failure: the CITRIS-ALI randomized clinical trial. JAMA. 2019;322(13):1261-1270.

28. Hager, D. N., Hooper, M. H., Bernard, G. R., Busse, L. W., Ely, E. W., Fowler, A. A., et al. (2019). The vitamin C, thiamine and steroids in sepsis (VICTAS) protocol: a prospective, multicenter, double-blind, adaptive sample size, randomized, placebo-controlled, clinical trial. Trials 20 (1), 197. doi:10.1186/s13063-019-3254-2

29. Li, J. (2018). Evidence is stronger than you think: a meta-analysis of vitamin $\mathrm{C}$ use in patients with sepsis. Crit. Care 22 (1), 258. doi:10.1186/s13054-018-2191-x

30. Putzu, A., Daems, A.-M., Lopez-Delgado, J. C., Giordano, V. F., and Landoni, G. (2019).

The effect of vitamin C on clinical outcome in critically ill patients. Crit. Care Med. 47 (6), 774783. doi:10.1097/CCM.0000000000003700

31. Iglesias, J., Vassallo, A. V., Patel, V. V., Sullivan, J. B., Cavanaugh, J., and Elbaga, Y. (2020). Outcomes of metabolic resuscitation using ascorbic acid, thiamine, and glucocorticoids in the early treatment of sepsis. Chest 158, 164-173. doi:10.1016/j.chest.2020.02.049 clinical trial. Eur. J. Clin. Pharmacol. 76 (2), 175-184. doi:10.1007/s00228-019-02788-w 32. Obi, J., Pastores, S. M., Ramanathan, L. V., Yang, J., and Halpern, N. A. (2020). Treating sepsis with vitamin $\mathrm{C}$, thiamine, and hydrocortisone: exploring the quest for the magic elixir. J. Crit. Care 57, 231-239. doi:10.1016/j.jcrc.2019.12.011

33. Noormandi, A., Khalili, H., Mohammadi, M., and Abdollahi, A. (2020). Effect of magnesium supplementation on lactate clearance in critically ill patients with severe sepsis: a randomized 34. Shan, M. R., Zhou, S. N., Fu, C. N., Song, J. W., Wang, X. Q., Bai, W. W., et al. (2020). Vitamin $B 6$ inhibits macrophage activation to prevent lipopolysaccharide-induced acute pneumonia in mice. J. Cell Mol. Med. 24 (5), 3139-3148. doi:10.1111/jcmm.14983 35. Uckun FM, Ozercan IH, Orhan C, Gitterle M, Sahin K. Rejuveinix Reverses Severe Inflammatory Lung Damage in a Mouse Model of Fatal Sepsis. Preprint from bioRxiv, 02 Jan 2021 DOI: 10.1101/2020.12.31.424986 PPR: PPR260178

36. Uckun FM, Orhan C, Powell J, Sahin E, Ozercan IH, Volk M, Sahin K. Non-clinical safety profile and pharmacodynamics of two formulations of the anti-sepsis drug candidate Rejuveinix (RJX). Biomed Pharmacother. 2021 Sep;141:111823. doi: 10.1016/j.biopha.2021.111823. Epub 2021 Jun 17. PMID: 34147902. 
37. A. Nair, S. Jacob, A simple practice guide for dose conversion between animals and human, J. Basic Clin. Pharm. 7 (2016) 27. https://doi.org/10.4103/0976-0105.177703.

38. S.H. Woolf, D.A. Chapman, J.H. Lee, COVID-19 as the Leading Cause of Death in the United States, JAMA - J. Am. Med. Assoc. 325 (2021) 123-124.

https://doi.org/10.1001/jama.2020.24865.

39. 1. World Health Organization. COVID-19 Weekly Epidemiological Update, edition 45. World Health Organization (2021).

\section{Google Scholar}

40. Hannah Ritchie, Edouard Mathieu, Lucas Rodés-Guirao, Cameron Appel, Charlie Giattino, Esteban Ortiz-Ospina, Joe Hasell, Bobbie Macdonald, Diana Beltekian and Max Roser (2020) "Coronavirus Pandemic (COVID-19)". Published online at OurWorldInData.org. Retrieved from: 'https://ourworldindata.org/coronavirus' [Online Resource]

41. Karlinsky A, Kobak D. The World Mortality Dataset: Tracking excess mortality across countries during the COVID-19 pandemic. medRxiv [Preprint]. 2021 Jun

4:2021.01.27.21250604. doi: 10.1101/2021.01.27.21250604. Update in: Elife. 2021 Jun 30;10: PMID: 33532789; PMCID: PMC7852240.

42. Zumla, A., Hui, D. S., Azhar, E. I., Memish, Z. A., Maeurer, M. (2020). Reducing mortality from 2019-nCoV: host-directed therapies should be an option. Lancet 395 (10224), e35-e36. doi: 10.1016/S0140-6736(20)30305-6

43. Freeman TL, Swartz TH. Targeting the NLRP3 Inflammasome in Severe COVID-19. Front Immunol. 2020 Jun 23;11:1518. doi: 10.3389/fimmu.2020.01518.

44. Fan E, Beitler JR, Brochard L, Calfee CS, Ferguson ND, Slutsky AS, Brodie D. COVID-19associated acute respiratory distress syndrome: is a different approach to management warranted? Lancet Respir Med. 2020 Aug;8(8):816-821. doi: 10.1016/S2213-2600(20)30304-0. 45. Chen W. A potential treatment of COVID-19 with TGF-b blockade. Int J Biol Sci 16: 19541955 (2020).

46. Stafford N, Arnold A, Jebakumar S, et al. Therapeutic strategies for COVID-19: new insights into the value of transforming growth factor beta $(\operatorname{tg} \beta)$ antagonists such as imatinib and other kinase inhibitors. BMJ 369: m1610 (2020).

47. Uckun F. M. (2020b). Reducing the fatality rate of COVID-19 by applying clinical insights from immuno-oncology and lung transplantation. Front. Pharmacol. 11, 796.

10.3389/fphar.2020.00796 [PMC free article] [PubMed] [CrossRef] [Google Scholar] 
48. Attaway AH, Scheraga RG, Bhimraj A, Biehl M, Hatipoğlu U. Severe covid-19 pneumonia: pathogenesis and clinical management. BMJ. 2021 Mar 10;372:n436. doi: 10.1136/bmj.n436. PMID: 33692022.

49. Cavalli G, Farina N, Campochiaro C, De Luca G, Della-Torre E, Tomelleri A, Dagna L. Repurposing of Biologic and Targeted Synthetic Anti-Rheumatic Drugs in COVID-19 and HyperInflammation: A Comprehensive Review of Available and Emerging Evidence at the Peak of the Pandemic. Front Pharmacol. 2020 Dec 18;11:598308. doi: 10.3389/fphar.2020.598308. PMID: 33442386; PMCID: PMC7798432.

50. W. H. O. Rapid Evidence Appraisal for COVID-19 Therapies Working Group. Shankar-Hari M, Vale CL, Godolphin PJ, Fisher D, Higgins JPT, Spiga F, Savovic J, Tierney J, Baron G, et al. Association between administration of IL-6 antagonists and mortality among patients hospitalized for COVID-19: a meta-analysis. JAMA. 2021;326:499-518. [PMC free article] [PubMed] [Google Scholar]

51. Recovery Collaborative Group Tocilizumab in patients admitted to hospital with COVID-19 (RECOVERY): a randomised, controlled, open-label, platform trial. Lancet. 2021;397(10285):1637-1645. [PMC free article] [PubMed] [Google Scholar] 52. Remap-Cap Investigators. Gordon AC, Mouncey PR, Al-Beidh F, Rowan KM, Nichol AD, Arabi YM, Annane D, Beane A, van Bentum-Puijk W, et al. Interleukin-6 receptor antagonists in critically ill patients with Covid-19. N Engl J Med. 2021;384(16):1491-1502. [PMC free article] [PubMed] [Google Scholar]

53. Recovery Collaborative Group. Horby P, Lim WS, Emberson JR, Mafham M, Bell JL, Linsell L, Staplin N, Brightling C, Ustianowski A, et al. Dexamethasone in hospitalized patients with Covid-19. N Engl J Med. 2021;384(8):693-704. [PMC free article] [PubMed] [Google Scholar] 54. Horby P., Lim W.S., Emberson J., Mafham M., Bell J., Linsell L., Staplin N., Brightling C., Ustianowski A., Elmahi E. Effect of dexamethasone in hospitalized patients with COVID-19: preliminary report. MedRxiv. 2020

55. Rees V. Dexamethasone could reduce COVID-19 patient death risk by one-third, study shows. Eur. Pharm. Rev. 2020

56. Group R.C. Dexamethasone in hospitalized patients with covid-19-preliminary report. N. Engl. J. Med. 2020 
57. Noreen S, Maqbool I, Madni A. Dexamethasone: Therapeutic potential, risks, and future projection during COVID-19 pandemic. Eur J Pharmacol. 2021 Mar 5;894:173854. doi:

10.1016/j.ejphar.2021.173854.

58. Tomazini BM, Maia IS, Cavalcanti AB, Berwanger O, Rosa RG, Veiga VC, Avezum A, Lopes RD, Bueno FR, Silva M, et al. Effect of dexamethasone on days alive and ventilator-free in patients with moderate or severe acute respiratory distress syndrome and COVID-19: the CoDEX randomized clinical trial. JAMA. 2020;324(13):1307-1316. [PMC free article] [PubMed] [Google Scholar]

59. Angus DC, Derde L, Al-Beidh F, Annane D, Arabi Y, Beane A, van Bentum-Puijk W, Berry L, Bhimani $Z$, Bonten $M$, et al. Effect of hydrocortisone on mortality and organ support in patients with severe COVID-19: the REMAP-CAP COVID-19 corticosteroid domain randomized clinical trial. JAMA. 2020;324(13):1317-1329. [PMC free article] [PubMed] [Google Scholar] 60. Jeronimo CMP, Farias MEL, Val FFA, Sampaio VS, Alexandre MAA, Melo GC, Safe IP, Borba MGS, Netto RLA, Maciel ABS, et al. Methylprednisolone as adjunctive therapy for patients hospitalized with coronavirus disease 2019 (COVID-19; Metcovid): a randomized, double-blind, phase IIb, placebo-controlled trial. Clin Infect Dis. 2021;72(9):e373-e381. [PMC free article] [PubMed] [Google Scholar]

61. S. Riphagen, X. Gomez, C. Gonzalez-Martinez, N. Wilkinson, P. Theocharis, Hyperinflammatory shock in children during COVID-19 pandemic, Lancet. 395 (2020) 16071608. https://doi.org/10.1016/S0140-6736(20)31094-1.

62. P. Davies, C. Evans, H.K. Kanthimathinathan, J. Lillie, J. Brierley, G. Waters, M. Johnson, B. Griffiths, P. du Pré, Z. Mohammad, A. Deep, S. Playfor, D. Singh, D. Inwald, M. Jardine, O. Ross, N. Shetty, M. Worrall, R. Sinha, A. Koul, E. Whittaker, H. Vyas, B.R. Scholefield, P. Ramnarayan, Intensive care admissions of children with paediatric inflammatory multisystem syndrome temporally associated with SARS-CoV-2 (PIMS-TS) in the UK: a multicentre observational study, Lancet Child Adolesc. Heal. 4 (2020) 669-677.

https://doi.org/10.1016/S2352-4642(20)30215-7.

63. E.M. Dufort, E.H. Koumans, E.J. Chow, E.M. Rosenthal, A. Muse, J. Rowlands, M.A. Barranco, A.M. Maxted, E.S. Rosenberg, D. Easton, T. Udo, J. Kumar, W. Pulver, L. Smith, B. Hutton, D. Blog, H. Zucker, Multisystem Inflammatory Syndrome in Children in New York State, N. Engl. J. Med. 383 (2020) 347-358. https://doi.org/10.1056/nejmoa2021756. 
64. L.R. Feldstein, E.B. Rose, S.M. Horwitz, J.P. Collins, M.M. Newhams, M.B.F. Son, J.W. Newburger, L.C. Kleinman, S.M. Heidemann, A.A. Martin, A.R. Singh, S. Li, K.M. Tarquinio, P. Jaggi, M.E. Oster, S.P. Zackai, J. Gillen, A.J. Ratner, R.F. Walsh, J.C. Fitzgerald, M.A. Keenaghan, H. Alharash, S. Doymaz, K.N. Clouser, J.S. Giuliano, A. Gupta, R.M. Parker, A.B. Maddux, V. Havalad, S. Ramsingh, H. Bukulmez, T.T. Bradford, L.S. Smith, M.W. Tenforde, C.L. Carroll, B.J. Riggs, S.J. Gertz, A. Daube, A. Lansell, A. Coronado Munoz, C. V Hobbs, K.L. Marohn, N.B. Halasa, M.M. Patel, A.G. Randolph, Multisystem Inflammatory Syndrome in U.S. Children and Adolescents, N. Engl. J. Med. 383 (2020) 334-346.

https://doi.org/10.1056/NEJMoa2021680. 
medRxiv preprint doi: https://doi.org/10.1101/2022.02.12.22270748; this version posted February 18,2022 . The copyright holder for this preprint (which was not certified by peer review) is the author/funder, who has granted medRxiv a license to display the preprint in perpetuity.

All rights reserved. No reuse allowed without permission.

\section{FIGURES AND TABLES}



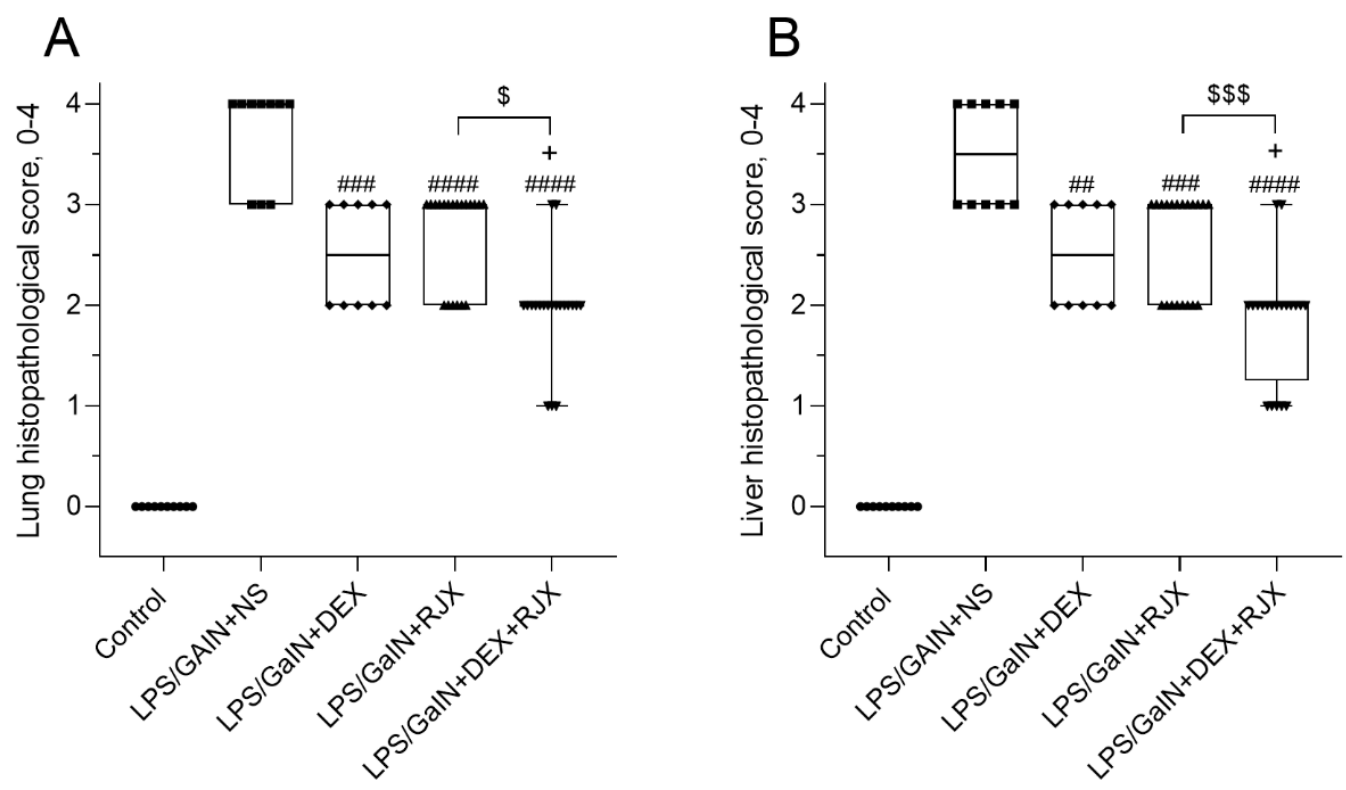

C

\begin{tabular}{llll}
\hline Lung Histopathological Score: $\geq 3$ & LPS-GalN +DEX & LPS-GalN +RJX & LPS-GalN +DEX+RJX \\
\cline { 2 - 4 } (severe damage or more) & $5 / 10(50.0 \%)$ & $14 / 20(70.0 \%)$ & $2 / 20(10.0 \%)$ \\
\hline pairwise & & $\mathrm{X}^{2}$ & $p$-value \\
LPS-GalN +DEX & LPS-GalN +RJX & 1.148 & $0.425^{\mathrm{a}}$ \\
LPS-GalN +DEX & LPS-GalN + DEX+RJX & 5.963 & $0.026^{\mathrm{a}}$ \\
LPS-GalN +RJX & LPS-GalN +DEX+RJX & 15.000 & 0.0001 \\
\hline
\end{tabular}

\begin{tabular}{llll}
\hline Liver Histopathological Score: $\geq 3$ & LPS-GalN +DEX & LPS-GalN +RJX & LPS-GalN +DEX+RJX \\
\cline { 2 - 4 } (severe damage or more) & $5 / 10(50.0 \%)$ & $12 / 20(60.0 \%)$ & $2 / 20(10.0 \%)$ \\
\hline pairwise & & $\mathrm{X}^{2}$ & $p$-value \\
LPS-GalN +DEX & LPS-GalN +RJX & 0.271 & $0.705^{\mathrm{a}}$ \\
LPS-GalN +DEX & LPS-GalN + DEX+RJX & 5.963 & $0.026^{\mathrm{a}}$ \\
LPS-GalN +RJX & LPS-GalN +DEX+RJX & 10.989 & 0.002 \\
\hline
\end{tabular}

Figure 1. In Vivo Treatment Activity of Rejuveinix (RJX), Dexamethasone (DEX), and RJX+DEX on Lung and Liver Histopathological Scores in the LPS-GalN Mouse Model of Fatal Cytokine Storm, Sepsis, Systemic Inflammation, ARDS and Multiorgan Failure. BALB/C mice were treated with i.p injections of RJX ( $\mathrm{n}=20,6$-fold diluted, $4.2 \mathrm{~mL} / \mathrm{kg}, 0.5 \mathrm{ml} / \mathrm{mouse}$ ), DEX ( $\mathrm{n}=10,6 \mathrm{mg} / \mathrm{kg}$, $0.5 \mathrm{~mL} /$ mouse), RJX + DEX ( $\mathrm{n}=20,0.5 \mathrm{~mL} /$ mouse), or vehicle (NS, $0.5 \mathrm{~mL} /$ mouse) two hours post-injection of LPS-GalN. Except for untreated control mice (Control, $n=10$ ), each mouse 
received $0.5 \mathrm{ml}$ of LPS-GalN (consisting of $100 \mathrm{ng}$ of LPS plus $8 \mathrm{mg}$ of D-galactosamine) i.p. The depicted Whisker plots represent the median and values. In (A), the lung histopathological score ("lung injury score") was graded according to a 5-point scale from 0 to 4 as follows: $0,1,2,3$, and 4 represented no damage, mild damage, moderate damage, severe damage, and very severe damage, respectively. In (B), the liver histopathological score ("liver injury score") was graded according to a 5-point scale from 0 to 4 as follows: 0, I, 2, 3, and 4 represented no damage, mild damage, moderate damage, severe damage, and very severe damage, respectively. KruskalWallis test and Mann Whitney $U$ test were used for comparing the results among different treatment groups. Statistical significance between groups is shown by \#\# $p<0.01$; \#\# $p<0.001$; \#\#\# p<0.0001 as compared to LPS/GalN+NS group, $+p<0.05$ as compared to LPS/GalN+DEX group, and $\$ p<0.05 ; \$ \$ p<0.001$ pairwise comparisons between the groups. In (C), for severe damage, lung and liver histological scores were compared by Pearson's Chi-Square or Fisher's Exact test. ${ }^{a}$ Fisher's Exact Chi-Square test used. 
A

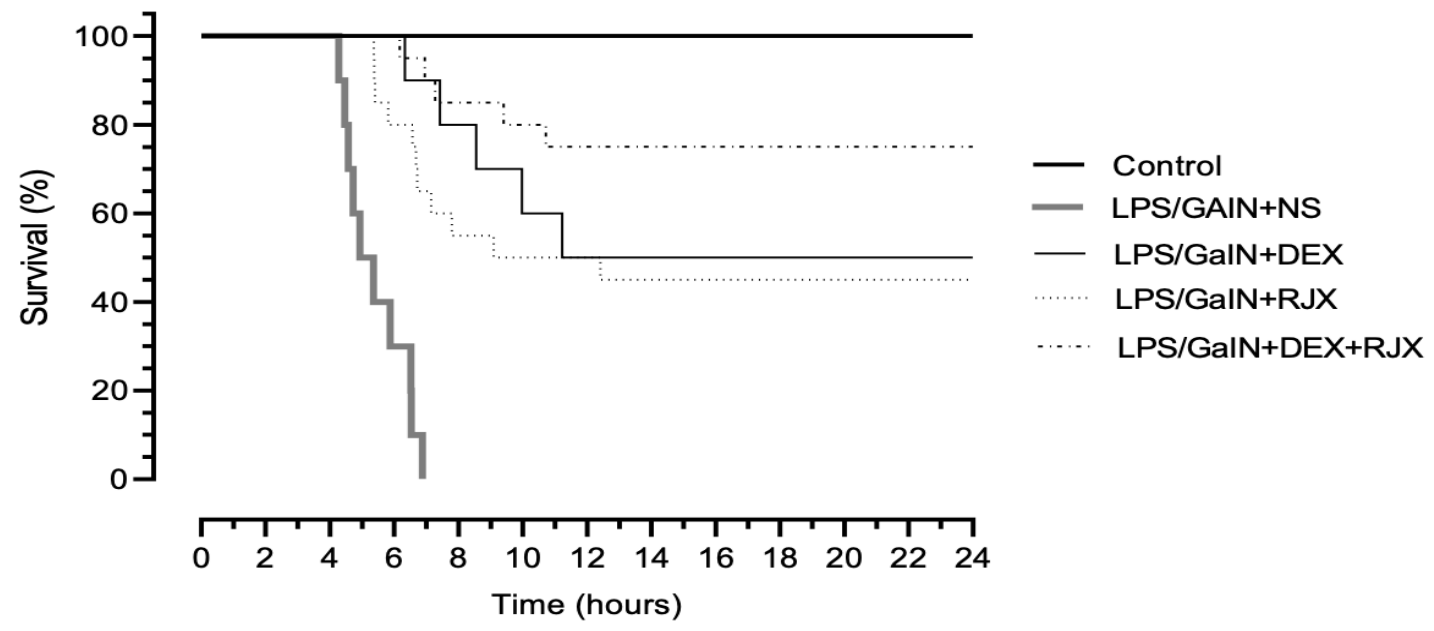

\begin{tabular}{|c|c|c|c|c|c|}
\hline B. Survival Analysis & Censored & $\begin{array}{c}\text { Fatal } \\
\text { Events }\end{array}$ & $\mathrm{n}$ & $\begin{array}{l}\text { Proportion } \\
\text { Dead at 24h }\end{array}$ & $\begin{array}{l}\text { Median } \\
\text { Survival } \\
\end{array}$ \\
\hline Control & 10 & 0 & 10 & $0.0 \%$ & $\geq 24 \mathrm{~h}$ \\
\hline LPS/GalN+NS & 0 & 10 & 10 & $100.0 \%$ & $5.1 \mathrm{~h}$ \\
\hline LPS/GalN+DEX & 5 & 5 & 10 & $50.0 \%$ & $17.6 \mathrm{~h}$ \\
\hline LPS/GalN+RJX & 9 & 11 & 20 & $55.0 \%$ & $10.8 \mathrm{~h}$ \\
\hline LPS/GalN+DEX+RJX & 15 & 5 & 20 & $25.0 \%$ & $\geq 24 \mathrm{~h}$ \\
\hline \multicolumn{3}{|l|}{ C. Pairwise comparisons } & \multicolumn{2}{|c|}{$\begin{array}{l}\text { Log-rank } \\
\text { Chi-square }\end{array}$} & $\begin{array}{l}p \text { value } \\
\text { summary }\end{array}$ \\
\hline Control & LPS/GalN+l & & 21.837 & 0.0001 & 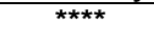 \\
\hline Control & LPS/GalN+L & & 6.389 & 0.0115 & * \\
\hline Control & LPS/GalN+t & & 7.624 & 0.0947 & ** \\
\hline Control & LPS/GalN+L & RJX & 2.793 & 0.0040 & ** \\
\hline LPS/GalN+NS & LPS/GalN+L & & 18.258 & 0.0001 & $\star \star \star \star *$ \\
\hline LPS/GalN+NS & LPS/GalN+t & & 20.151 & 0.0001 & **** \\
\hline LPS/GalN+NS & LPS/GalN+L & RJ & 36.369 & 0.0001 & 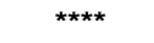 \\
\hline LPS/GalN+DEX & LPS/GalN+t & & 0.313 & 0.5759 & ns \\
\hline LPS/GalN+DEX & LPS/GalN+L & RJX & 1.583 & 0.2083 & ns \\
\hline LPS/GalN+RJX & LPS/GalN+L & RJX & 4.365 & 0.0367 & * \\
\hline $\begin{array}{l}\text { LPS/GalN + Monotherapy } \\
\text { DEX or RJX }\end{array}$ & LPS/GalN+L & $2 J x$ & 3.977 & 0.0461 & * \\
\hline
\end{tabular}

Figure 2. In Vivo Treatment Activity of Low Dose Rejuveinix (RJX), Standard Dose Dexamethasone (DEX), and Their Combination in the LPS-GaIN Mouse Model of Fatal Cytokine Storm, Sepsis, Systemic Inflammation, ARDS and Multiorgan Failure. BALB/C mice were treated with i.p injections of RJX ( $n=20,6$ fold diluted, $4.2 \mathrm{~mL} / \mathrm{kg}, 0.5 \mathrm{ml} / \mathrm{mouse}$ ), DEX ( $\mathrm{n}=10,0.6 \mathrm{mg} / \mathrm{kg}, 0.5 \mathrm{~mL} / \mathrm{mouse}), \operatorname{RJX}+\mathrm{DEX}(\mathrm{n}=20,0.5$ $\mathrm{mL} /$ mouse), or vehicle (NS, $0.5 \mathrm{~mL} /$ mouse) two hours post-injection of LPS-GalN. Except for untreated control mice (Control, $\mathrm{n}=10$ ), each mouse received $0.5 \mathrm{ml}$ of LPS-GalN (consisting of $100 \mathrm{ng}$ of LPS plus 8 $\mathrm{mg}$ of D-galactosamine) i.p. The cumulative proportion of mice remaining alive (Survival, \%) is shown as a function of time after the LPS-GalN challenge. Depicted are the Kaplan Meier survival curves (Panel A) and survival data with statistical analysis (Panels B and C) of the different treatment groups. 

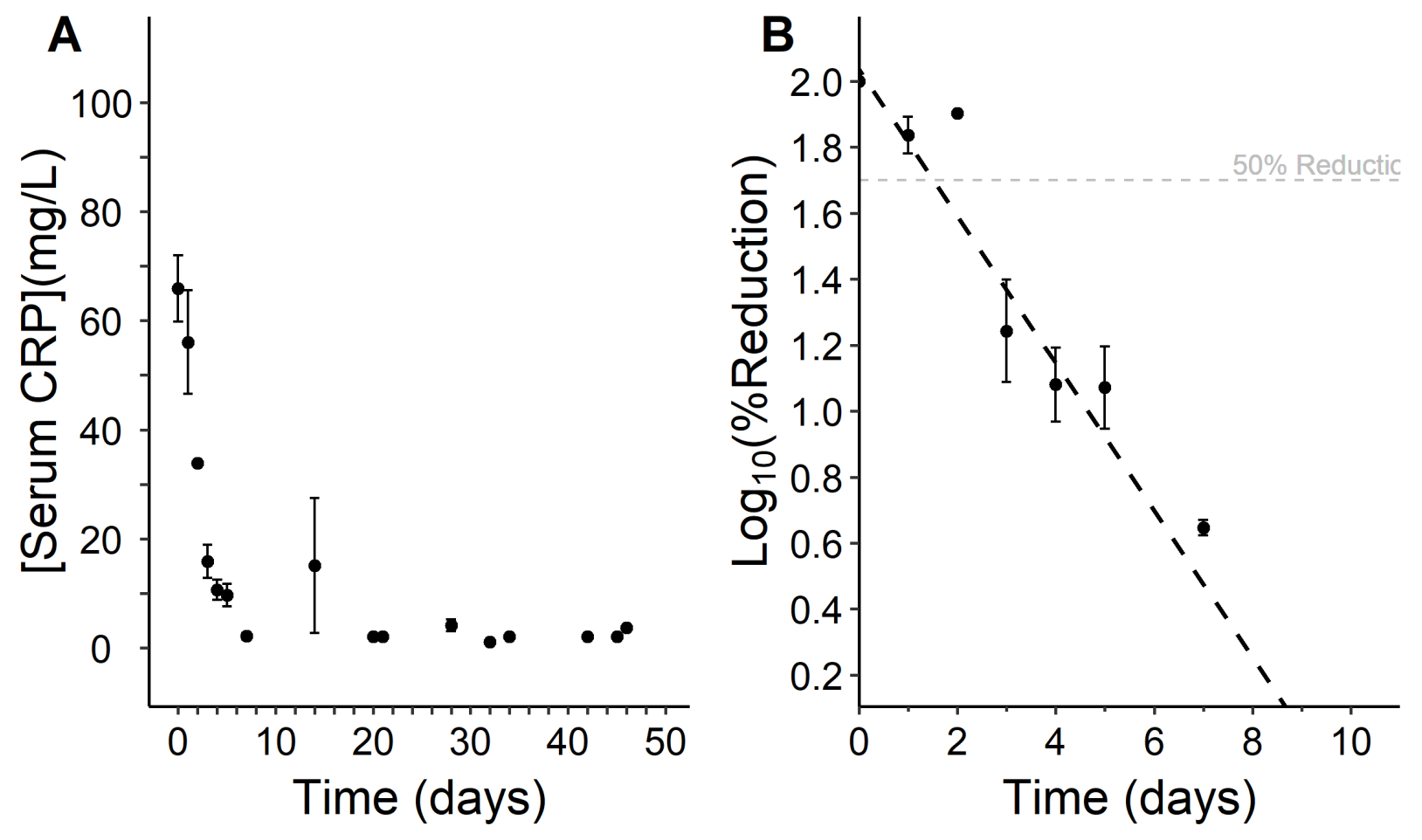

Figure 3. Time-dependent decrease of CRP Values in RJX-Treated Severe COVID-19 Patients. [A] Serum CRP concentration is depicted over 46 days for 9 evaluable responders [B] The first order kinetics of the reductions in serum CRP values was investigated by fitting a straight line to a semi-log plot of the portion of the CRP concentration $x$ time curve that displayed maximum reduction in CRP values over the course of RJX treatment. There were 36 independent data points across 7 days. The slope of the line represents the rate constant for CRP reduction in $\log _{10}$ scale (viz.: -0.2231 ). Time to $50 \%$ reduction $\left(T_{50}=1.5\right.$ days) of serum CRP values was calculated using the rate constant and intercept value of 2.04. Equation of the line: $\log _{10}(\%$ Reduction $)=-0.22309 \times$ Time$($ Days $)+2.04$. 

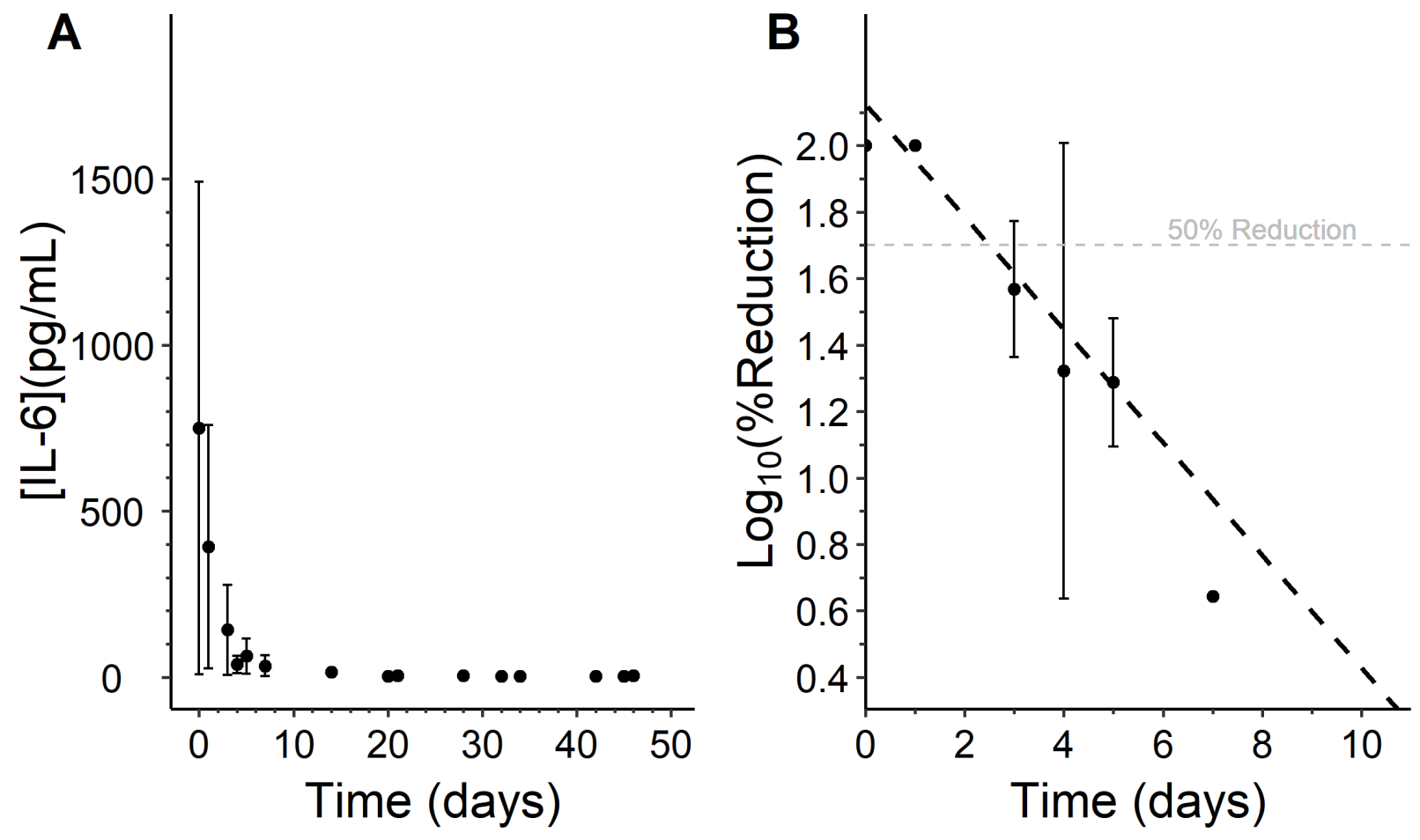

Figure 4. Time-dependent Reduction of Serum IL-6 Concentration in RJX-Treated Severe COVID-19 Patients. [A] Serum IL-6 concentration is depicted over 46 days for 5 evaluable responders $[B]$ The first order kinetics of the reductions in serum IL-6 values was investigated by fitting a straight line to a semi-log plot of the portion of the IL- 6 concentration $x$ time curve that displayed maximum reduction in IL-6 values over the course of RJX treatment. There were 18 independent data points across 7 days. The slope of the line represents the rate constant for IL-6 reduction in $\log _{10}$ scale (viz.: -0.1698$)$. The time to $50 \%$ reduction $\left(\mathrm{T}_{50}=\right.$ 2.5 days) of serum IL-6 values was calculated using the rate constant and the intercept value of 2.13. Equation of the line: $\log _{10}(\%$ Reduction $)=-0.16983 \times$ Time(Days $)+2.13$. 

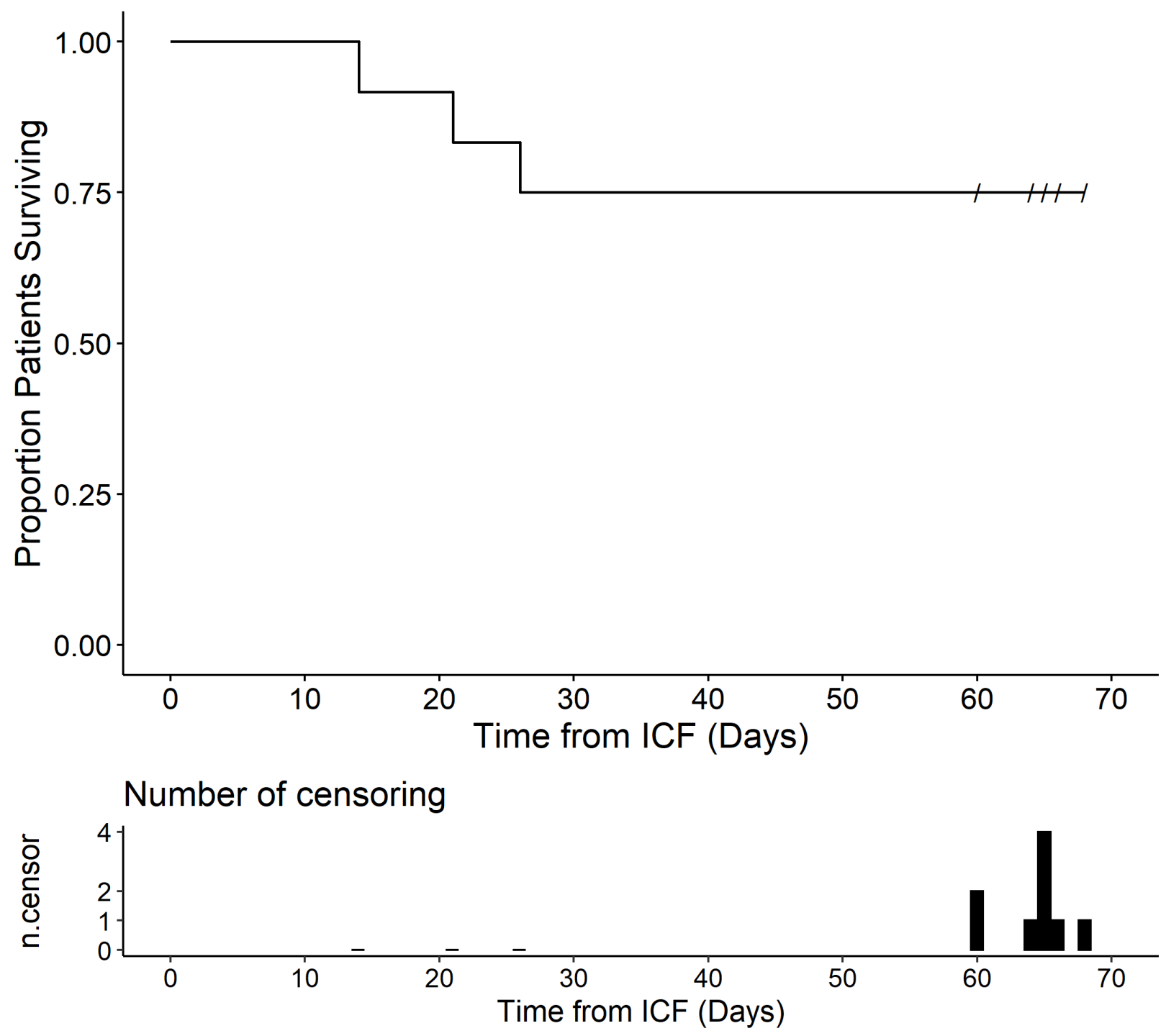

Figure 5. Survival Outcome of Severe COVID-19 Patients Treated with RJX Plus SOC. Depicted is the overall survival curve of the 12 hospitalized COVID-19 patients shown in Figure 3 along with the corresponding censor plot. All patients were treated with RJX + institutional SOC. Nine patients recovered and remained alive for $\geq 60$ days. 


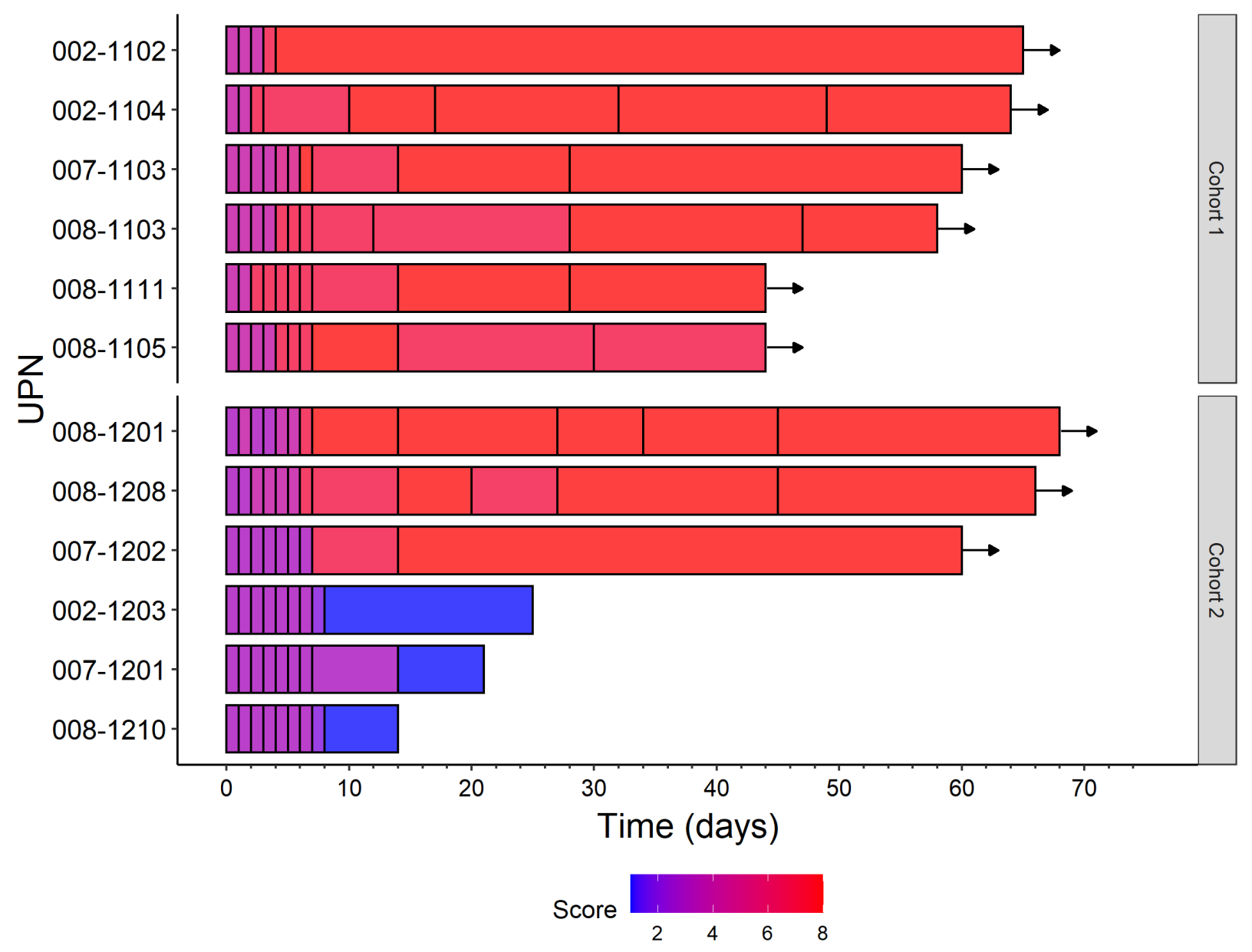

Figure 6. Swimmer plot of clinical health score changes in RJX treated COVID-19 patients. Scores according to the 8-point ordinal scale are indicated with different colors. Arrow: Alive. 
Table 1: Treatment Outcome of Patients in Part 1 of RPI015 Study

\begin{tabular}{|c|c|c|c|c|c|c|c|c|c|c|c|}
\hline \multirow[t]{2}{*}{ Patient No. } & \multirow[t]{2}{*}{ Cohort\# } & \multirow{2}{*}{$\begin{array}{c}\text { Progression } \\
\text { of COVID-19 } \\
\text { and NIV } \\
\text { Failure }\end{array}$} & \multirow{2}{*}{$\begin{array}{c}\text { Required } \\
\text { IMV }\end{array}$} & \multirow{2}{*}{$\begin{array}{l}\text { Time to IMV } \\
\text { (Time to } \\
\text { death) }\end{array}$} & \multicolumn{2}{|c|}{ Clinical Improvement } & \multirow{2}{*}{$\begin{array}{c}\text { CXR/CT } \\
\text { Improvement } \\
\text { at Discharge } \\
\text { from Hospital }\end{array}$} & \multirow{2}{*}{$\begin{array}{l}\text { Recovery on } \\
\text { 8-point } \\
\text { Ordinal Scale }\end{array}$} & \multicolumn{3}{|c|}{ Patient status at the last follow-up date } \\
\hline & & & & & $\begin{array}{c}\text { Time from } 1^{\text {st }} \text { dose of } \\
\text { RJX to Resolution of } \\
\text { HRF } \\
\text { (Time to Discharge) } \\
\text { in Days } \\
\end{array}$ & $\begin{array}{l}\text { COVID-19 } \\
\text { Symptoms } \\
\text { Improved/ } \\
\text { Resolved }\end{array}$ & & & $\begin{array}{l}\text { Last follow-up } \\
\text { date (Days from } \\
\text { ICF) }\end{array}$ & $\begin{array}{c}\text { Status } \\
\text { (Alive/Dead) }\end{array}$ & $\begin{array}{c}\text { ECOG } \\
\text { Performance } \\
\text { Status }\end{array}$ \\
\hline 002-1102 & 1 & No & No & NA(NA) & NA (4) & $+/+$ & NA & +3 & 65 & Alive & 0 \\
\hline $002-1203$ & 2 & Yes & Yes & $8(26)$ & NA (NA) & $-/-$ & NO & $\begin{array}{l}-2 \text { (no } \\
\text { recovery) }\end{array}$ & 26 & Dead & 5 \\
\hline $002-1104$ & 1 & No & No & NA(NA) & NA (3) & $+/+$ & NA & +3 & 64 & Alive & 0 \\
\hline $008-1201$ & 2 & No & No & $N A(N A)$ & $5(7)$ & $+/+$ & YES & +5 & 68 & Alive & 0 \\
\hline 008-1103 & 1 & No & No & $\mathrm{NA}(\mathrm{NA})$ & NA (5) & $+/+$ & YES & +3 & 65 & Alive & 0 \\
\hline $008-1105$ & 1 & No & No & $\mathrm{NA}(\mathrm{NA})$ & NA (5) & $+/+$ & NO & +4 & 65 & Alive & 0 \\
\hline $008-1208$ & 2 & No & No & NA (NA) & $3(7)$ & $+/+$ & YES & +5 & 66 & Alive & 0 \\
\hline $008-1210$ & 2 & Yes & Yes & $8(14)$ & $\mathrm{NA}(\mathrm{NA})$ & $-/-$ & NA & $\begin{array}{l}-2 \text { (no } \\
\text { recovery) }\end{array}$ & 14 & Dead & 5 \\
\hline $007-1201$ & 2 & $\mathrm{No}^{*}$ & No & $21(21)$ & NA (NA) & $-/-$ & NA & $\begin{array}{l}-2 \text { (no } \\
\text { recovery) }\end{array}$ & 21 & Dead & 5 \\
\hline 007-1202 & 2 & No & No & NA (NA) & $14(14)$ & $+/-^{a}$ & NA & +4 & 60 & Alive & 0 \\
\hline $008-1111$ & 1 & No & No & NA (NA) & NA (3) & $+/+$ & NO & +3 & 65 & Alive & 0 \\
\hline $007-1103$ & 1 & No & No & NA (NA) & NA (7) & $+/+$ & NA & +4 & 60 & Alive & 0 \\
\hline
\end{tabular}

Covid-19: Corona virus disease 2019; NIV: Non-invasive ventilation; IMV: Invasive mechanical ventilation; ICF: Informed consent form; RJX: Rejuveinix; ${ }^{0} 007-1202$ reported mild residual shortness of breath at last follow-up

8-point Ordinal Scale:

1. Death

2. Hospitalized, on invasive mechanical ventilation or ECMO

3. Hospitalized, on non-invasive ventilation or high flow oxygen devices

4. Hospitalized, requiring supplemental oxygen

5. Hospitalized, not requiring supplemental oxygen - requiring ongoing medical care (COVID-19 related or otherwise)

6. Hospitalized, not requiring supplemental oxygen - no longer requires ongoing medical care

7. Not hospitalized, limitation on activities and/or requiring home oxygen

8. Not hospitalized, no limitations on activities

ECOG Activity Level:

0 - Fully active, able to carry on all pre-disease performance without restriction; 1 - Restricted in physically strenuous activity but ambulatory and able to carry out work of a light or sedentary nature, e.g., light housework, office work; 2 - Ambulatory and capable of all selfcare but unable to carry out any work activities. Up and about more than $50 \%$ of waking hours.

3 - Capable of only limited selfcare, confined to bed or chair more than $50 \%$ of waking hours; 4 - Completely disabled. Cannot carry on any selfcare. Totally confined to bed or chair.

5 - Dead. *007-1201: The HRF did not worsen but patient developed and died of mesenteric ischemia and cardiac arrest as Grade 5 SAEs.

Patient 008-1204 who withdrew his consent on day 4 is not shown in this table but included in safety analyses shown in Table S4, Table S5, and Table S6. 